\title{
Bir Seyirci Araştırmasından Etnografik Deneyimler ve Hikâyeler
}

\section{An Ethnographic Experiences and Stories from a Spectator Research}

\section{Hasan Akbulut ${ }^{*}$}

\begin{abstract}
Özet
Çoğunlukla metin merkezli olmakla eleştirilen film çalışmaları alanında seyirciyi araştırmak, araştırma alanını da filmden, daha kapsayıcı olan sinemaya genişletmiştir. Seyirci, bir filmin seyredeni, alımlayanı ve anlamlandıranı olmanın da ötesinde, sinema salonuna gelip çeşitli koşullarda ve bağlamlarda filmi seyreder, sinema salonunda diğer seyircilerle etkileşir, sinemaya gidiş-geliş yolunda farklı bir dizi edimde bulunur. Sinemaya gitme deneyimi olarak adlandırılan bu süreç, farklı tarihsel, toplumsal, ekonomik ve kültürel bağlamlarda çeşitlenir. 115K269 No'lu "Kültürel ve Toplumsal Bir Pratik Olarak Sinemaya Gitmek: Türkiye'de Seyirci Deneyimleri Üzerine Bir Sözlü Tarih Çalışması” başlıklı TÜBİTAK projesi verilerine dayanan bu makale, Türkiye'de seyircinin kitlesel olarak sinemaya giderek film seyrettiği 1960'lı ve 1970'li yılları temel alarak, bu yıllardaki seyirci deneyimlerini saptama ve açıklamada kullanılan sözlü tarih görüşmeleri sürecine odaklanmaktadır. Sahada seyirciyle çalışırken, araştırmacı ve seyirci ekseninde yaşanan etnografik deneyimleri konu edinen makalede, İstanbul, Ankara, Antalya ve Kocaeli'nde yüz kişi ile yapılan sözlü tarih görüşmesi üzerinden, hem sahada se-
\end{abstract}

* İletişim Fakültesi Radyo, Televizyon ve Sinema Bölümü Sinema Anabilim Dalı. hasan.akbulut@istanbul.edu.tr 
yirci deneyimleri hem de araştırmacıların sahada seyirciyle çalışırken yaşadıkları deneyimleri özdüşünümsel biçimde yorumlanmıştır.

Anahtar sözcükler: sinemaya gitmek, seyirci, sözlü tarih, etnografik deneyim, özdüşünümsellik

\begin{abstract}
Researching the audience in the field of film studies, mostly criticized as being textcentered. Thatswhy the concept of researching and understanding audience has evolved from "film" to more inclusive concept called as "cinema". The spectator watches the film, receives and makes a sense of it. But beyond that, while the spectator comes to the cinema hall and watches the film on various conditions and contexts, he/she interacts with other audiences in the cinema, and has a different set of actions on the way to cinema. This process, called the experience of cinemagoing, varies in different historical, social, economic and cultural contexts. This article, based on the project which is supported by TUBITAK and titled "Cinemagoing as a Cultural and Social Practice: An Oral History Study on Spectators's Experiences in Turkey 1960s' and 1970s" with number 115K269. This paper also describes the mass audience watch cinema films in Turkey increasingly based on the 1960s and 1970s and focuses on the oral history interviews process used to identify and explain the spectator experiences these years. In the article, which deals with the ethnographic experiences that are collected based on the axis of the researcher and spectator while working with the audiences in the field, through oral history interviews with hundreds of people in Istanbul, Ankara, Antalya and Kocaeli, both the spectator experiences in field and the experiences lived by the researchers while they were working with the spectator were interpreted in a self-reflexive way.
\end{abstract}

Keywords: cinemagoing, spectator, oral history, ethnographic experiences, selfreflexivity

\title{
Metodolojik bir başlangıç: Sahada seyirciyle çalışmak
}

Deneyim, başımızdan geçen bir olay olduğu kadar, bu olayın kişide bıraktığı, onu güçlendiren, etkileyen bir süreci de kapsar. Francesco Casetti, "Sinemasal Deneyim" adlı çalışmasının başında deneyim kavramını etraflıca şöyle açıklıyor:

"Deneyim terimi burada belirli (ve bağlayıcı) bir anlamda kullanılmaktadır. Bir yandan, bizi şaşırtan ve ele geçiren bir şeye maruz kalmak (deneyimlemek) anlamına gelir. Diğer yandan bu maruz kalma durumunu bilgiye ve güce dönüştürmek, bir diğer deyişle söz konusu şeylerin üstesinden gelme becerisine sahip olduğumuz için birikimli hale gelmekle (“deneyim sahibi olmak") ilişkilendirebilir. Sinemasal deneyim, hem perdedeki görüntülerin (ve seslerin) mağrur bir biçimde duyularımızı işgal ettiği âna, hem 
de bunların düşünümsel olarak ne izlediğimize ve izleme eylemine dair bir farkındalığ tetiklediği âna denk düşmektedir. Bu durumda çarpıcı bir şeyle karşı karşıya kaldığımızda dikkatimiz keskinleşir, nasıl bakmamız gerektiğini ve bakmakta olduğumuzu da biliriz. Bu bizi başımıza gelen şeylerin kahramanı haline getirir. Bu bakış açısına göre, sinemasal deneyim, film alımlamasından -bir yorumdan veya bir tüketimden- daha fazlasıdır. Bu, duyusal veya bilişsel "ifratı" (alışılmışın dışında bize hitap eden ve dokunan şeyler vardır), karşılaştığımız şeyin ve bir şeyle karşılaştığımız gerçeğinin "farkındalığına" (bu farkındalık kendimizi ve çevremizi yeniden tanımlamamızı sağlar) bağlayan bir durumdur. İfrat ve farkındalık: Bu iki öğe sayesinde izlediğimiz şeyle yeniden bağ kurarak, bir durum "yaşıyoruz", aynı zamanda izlediğimizi anlam vererek çerçeveliyoruz. Bu iki öğe sayesinde şeylerle karşı karşıya geliyoruz, aynı zamanda hayatımızı yeni olaylarla yüzleşebilecek ölçüde zenginleştiriyoruz” (Casetti, 2011: 81).

Casetti'den yaptığımız bu uzun alıntı, deneyimin ikili niteliğini hem de sinemasal deneyimin katmanlı çehresini açımlıyor. Her ne kadar bu çalışmanın odağı, sinemaya giden seyircinin film aracılığıyla geçirdiği sinemasal deneyim ile sınırlı olmasa da, bu deneyimin sürecini ve deneyime eşlik eden aktörleri ortaya koyması bakımından yol gösterici. Bu çalışma, seyircinin araştırıldığı 115K269 No'lu "Kültürel ve Toplumsal Bir Pratik Olarak Sinemaya Gitmek: Türkiye'de Seyirci Deneyimleri Üzerine Bir Sözlü Tarih Çalışması" başlıklı TÜBİTAK projesi kapsamında dört araştırmacının dört kentte, daha özelde ise kendimin İstanbul'da gerçekleştirdiği saha çalışmasına odaklanarak, sahada araştırma sürecine, seyirci-katılımcılarla ilişkisine ve kendisine dair düşünüşlerini ortaya koymayı amaçlıyor. Bu yönüyle çalışma, seyircinin sinemaya gitme deneyimini kuramsal bir çerçevede anlamaktan çok, sahada araştırmacının yaşadığ deneyimlere odaklanıyor. Bir başka deyişle bu çalışmanın odağı seyirci değil, seyirciyi konu edinen araştırmacı olarak ben. Buna vesile olan süreç ise, Türkiye'de seyircinin kitlesel olarak sinemaya giderek film seyrettiği 1960'lı ve 1970'li yılları temel alarak, bu yıllardaki seyirci deneyimlerini saptama ve açılamada kullanılan sözlü tarih görüşmeleri olmuştur. Bu proje, 1960-1980 yılları arasında, yani Yeşilçam döneminde sinemaya gitmiş, sinema kültürünü deneyimlemiş kişilerle, 2016-2017 yılları arasında yapılan görüşmelere dayanmaktadır. Bu görüşmeler, görüşme odağını sinema kültürü üzerinde tutmak için, yarı yapılandırılmış formlar ekseninde gerçekleştirilmiştir. Projede kullanılan sözlü tarih yöntemi ve görüşme tekniği, sözlü tarih, bellek ve sinemaya gitmeye dair literatür incelemelerine dayanmaktadır. Araştırmada kullanılan sözlü tarih görüşme formu, Anette Kuhn (2002) başta olmak üzere, öncü araştırmacıların çalışmaları incelendikten, daha evvel araştırmacının da katıldığı sözlü tarih araştırma projeleri dikkate alınarak "konu yönelimli/ epizodik" (Thompson, 1999) biçimde, tarafımdan hazırlandı. Görüşme formunda, görüşmecilerin sosyo-demografik verilerinden başlamak üzere, geçmişte yaşadıkları yere ve döneme, dönemin önemli tarihsel, toplumsal olaylarına, serbest zaman etkinliklerine, sinema kavrayışlarına, sinemaya gitme pratiklerine dair sorular yer aldı. Geçmişin sinema seyirciliğine dair anımsatıcı bir nitelikte olması planlanan bu sorularla, belleği canlandırmak amaçlandı. Öznelerin, araştırılan dönemlerdeki demografik, 
sosyal, ekonomik, kültürel ve de politik konumları itibariyle kendilerini anlatmalarıyla başlayan görüşmeler, dönemin serbest zaman ve kültürel etkinliklerinin neler olduğuna, daha sonrasında da sinemaya odaklanarak devam etti. Özneleri, kendi ilişkisellikleri içinde kavramaya çalıştığımız bu süreç, onların duygu ve düşüncelerini de ifade etmelerine olanak verdi. Böylece görüşmecilerin ve benim, gündelik hayat rutini, davranışlar, sözler, sessizlikler, bekleyişler gibi görüşme sürecinde yaşanan bir dizi gözlemlenebilir ve hissedilebilir örüntü, duygu, inanç ve söylemleri ile birlikte ortaya konduğu etnografik bir araştırma süreci yaşandı. Sözlü tarih ya da Kottak'ında ifade ettiği haliyle (2002: 30-31) söyleşi, görüşme ve görüşme izlenceleri, yalnızca bir kayıt faaliyeti değildir, aynı zamanda görüşme hazırlı̆̆ 1 , görüşme süreci ve görüşme sonrası katılımcı gözlemin kullanıldığı bir etnografik araştırma tekniklerinden biridir. Tekniği etnografik kılan şey, görüşme izlencesini kullanırken kaynak kişilerle yüz yüze konuşulması, sorular sorulup, yanıtların kaydedilmesidir (Kottak, 2002: 31). Ayrıca sözlü tarih görüşmeleri, kaynak kişilerin kendi içinde, görüşmeci ile görüşen, katılımcılar ile onların kültürleri arasında birçok etkileşim katmanını oluşturmasıyla da (Abrams, 2016), etnografik bir içeriğe sahiptir. Nitel bir araştırma yöntemi olan etnografi, genelde etnografın açık ya da gizli olarak belirli bir zaman içinde insanların gündelik yaşamlarına girip olanları gözleyerek, konuşulanları dinleyerek ve informal ve formal görüş̧melerle sorularak sorarak, incelemenin odağı olan konular üzerine 1 şık tutacak erişilebilir belge ve materyal toplayarak katılarak gözlem yapmasını içerir (Hammersley ve Atkinson 2007: 3).

Emerson ve arkadaşları da bu tanımdaki öğeleri yineleyerek (2008: 1) araştırmac1nın, belirli bir topluluğu veya kültürü anlayıp, anlaşılır kılabilmek için içerden bilgiye ulaşma adına, çalışma yaptı̆̆ı insanların gündelik yaşamlarına, doğal hali içerisinde bizzat katılarak girmesine bağlı olarak kuracağı yakın ve sürekli ilişkiler sayesinde edineceği gözlemleri, aldığı notları, duyduğu konuşmaları kayıt altına alarak yaptığı betimleyici tarzdaki anlatılardan oluşan yaklaşım tarzıyla üretilen metinler olarak tanımlar. Etnograf bu süreçte olabildiğince "araştırılan insanların anlam dünyalarına dâhil olmakta, düzenlenmiş faaliyetlerden oluşan sisteme katılmakta ve onların ahlâk düzeninin kodlarına tabii olduğunu hissetmektedir". Katılım arttıkça da "etnograf, olan bitene kayıtsız kalamamaya" da başlar (Emerson vd., 2008: 3).

Creswell (2012: 464) nitel araştırma tasarımlarından biri olan etnografik araştırma tasarımının gerçekçi etnografi, örnek olay ve eleştirel etnografi olmak üzere üç temel biçimi olduğunu belirtir. Yazarın tanımladığı gibi gerçekçi etnografi, Van Maanen (1988) tarafından karakterize edilen ve araştırmacı tarafından incelenen bireylere yönelik belirli bir duruşu yansıtmaktadır.

"Gerçekçi etnografi, durumun nesnel bir değerlendirmesi olup, tipik olarak üçüncü şahıs bakış açısıyla yazılmıştır ve bir saha çalışmasında katılımcılardan öğrendiklerini nesnel olarak raporlar. Bu yaklaşımda etnograf, çalışmayı üçüncü şahıs tarafından tutkusuz bir sesle anlatır ve katılımcıların gözlemleri ve görüşlerini raporlar. Etnograf, araştırma raporunda kişisel görüş bildirme olanağ sunmaz ve "gerçekler" in her 
şeyi bilen muhabiri olarak arka planda kalır. Araştırmacı, nesnel verileri, kişisel önyargı, politik hedefler ve yargı tarafından kirletilmemiş ölçülü bir tarzda rapor eder. Etnograf, katılımcıların görüşlerini, oldukça düzenlenmiş alıntılarla sunar ve kültürün yorumlanması ve sunumu ile ilgili son sözü söyler" (Van Maanen, 1988'den akt. Creswell, 2012: 464).

Creswell'in ikinci kategori olarak ayırdığı güç, statü, ayrımcılık gibi toplumsal sorunların eksende olduğu eleştirel etnografide araştırmacı, yorumların, kendi tarih ve kültürünü yansıttığını bildiğinden, kendi yorumları hakkında öz-bilinçlidir. "Yorumlar yalnızca geçici olabilir ve katılımcıların bunları nasıl izleyeceği ile ilgilidir. Eleştirel araştırmacılar kendilerini metne, düşünümsel ve kendi rollerinin farkında olarak yerleştirirler ve bunu araştırma raporunda öne çıkarırlar. Bu, önyargıların ve değerlerin tanımlanması; görüşleri kabul etmek ve yazar, katılımcılar ve okur tarafından metinsel sunumlar arasında ayrım yapılması anlamına gelir. Artık etnograf, gerçekçi yaklaşımda olduğu gibi "nesnel” bir gözlemci değildir. Eleştirel araştırmacı için bu tarafsı olmayan konum, aynı zamanda, onun, insanların daha az ezilen ve marjinalize edilmiş olmasını sağlamak için, toplumda değişiminin savunucusu olacağı anlamına da gelir. Sonuçta, eleştirel etnografik rapor, çelişkiler, tahmin edilemeyen şeyler ve gerginliklerle dolu 'soruna karışık, çok seviyeli, çok yöntemli bir yaklaşım' olacaktır (Denzin, 1997'den akt. Creswell, 2012: 467).

"Düşünümsellik, etnografik çalışmanın bağlamını, nasıl ve hangi koşullar altında yapılıp yazıldığını, araştırmayı yönlendiren etmenleri kritik olarak düşünmenin gerekliliğine vurgu yapar” (Nahya, Rahmanşah, 2016: 24). Bu etmenler, araştırmacının çalışma konusuyla, alanla, alanda insanlarla ve kendisiyle kurduğu ilişkileri ve konumu ile çalışmaya etki eden daha genel tarihsel, toplumsal, ekonomik, politik bağlamın farkında olmak anlamına gelir. Özdüşünümsel metinlerde bir katılımcı olarak araştırmacı ve onun deneyimleri oda olsa da, Hervik (1994), düşünümselliği, öznel bir içebakış olmaktan çok, yazarın konumu ile metnin üretiminin soruşturulması olarak görür ve birbiriyle kesişen katmanlı bir yapı olarak tasarlar. Alanda etnograf, sosyal deneyimlerini ve akıl yürütmelerini paylaşarak kültürel modellerde depolanmış kolektif inançlara dair içgörü elde eder; bu bürünsel (holistik) deneyimde etnografın öz-düşünümselliği, diğer özdüşünümselliklerle karşılaşır ve etkileşir. Sonuçta nesnellik karşıtı bir form olarak değil, aynı zamanda tek nesnelleştirme tarzımız olarak göreliliğin deneyimi olan bir yeni bir tür özdüşünümsellik, "paylaşılan öz-düşünümsellik” ortaya çıkar (Arderner, 1989: 212221'den akt. Hervik, 1994: 96). Tam da bu yönüyle etnografik araştırma ve yazımı, Marcus ve Fisher' in "tanımlaması ile potansiyel olarak bir deneydir, gebe bir andır" (2013: 10). Yazarlar, yerel sözel anlatıları edebi biçimler olarak okumak gibi çalışmaları içeren bu yeni etnografik poetika içerisinde, diyalojik, yorumbilgisel yorumlama çerçevelerini, antropologlarım ürettiği edebi eserleri, etnografik filmler ve kurmacalar ile deneyimin farklı temsil biçimlerini sıralarlar (Marcus, Fisher, 2013: 121, 122). Postmodern ya da yeni yaklaşımlarda etnografi, “deneyimin anlamının kaydıdır. Deneyim, etnografiden 
bağımsız davranış, anlamlar, metinler vb. gibi diğerlerinden daha bağımsız bir nesne değildir" (Tyler, 1986: 138).

Deneyimin temsili, yukarıda vurgulandığı gibi, araştırmacının özdüşünümselliğini ve araştırılan yerel topluluk ile diyalojik bir ilişkisini gerektirir ki, bu yazı, bu tartışmalar beslenerek yazıldı. Sahada seyirciyle çalışırken araştırmacı ve seyirci ekseninde yaşanan etnografik deneyimleri konu edinen bu çalışmada, İstanbul, Ankara, Antalya ve Kocaeli'nde yüz kişi ile yapılan sözlü tarih görüşmesi üzerinden, hem sahada seyirci deneyimleri hem de araştırmacıların sahada seyirciyi, seyirciyle çalışırken yaşadıkları deneyimler özdüşünümsel biçimde yorumlanmaya çalışıldı. Gupta ve Ferguson'un belirttiği gibi, "sahanın metinsel olarak dağınık notları ile düşünümsel, kuramsal, cilalanmış, metinlerarası metinsel bir bütün olan" evin metnini" kapsayan etnografik deneyimler" (1997: 12) bu yazının odağına yerleştirildi. Araştırma sürecinde ekip olarak çalışsak ve ekip olarak benzer deneyimleri yaşasak da, çalışmada görüşmeci seçiminden başlayıp, araştırmacı olarak benim sahada katılımcılarla ve kendimle kurduğum ilişki biçimini, araştırma sürecinde yaşadığım çarpıcı olayları ve deneyimleri anlatmak ve paylaşmak istiyorum.

\section{Katılımcılara erişim ve ikna süreci}

Bir sözlü tarih görüşmesi öncelikle katılımcı ile kurulacak güven ilişkisine dayanır. Güvenin inşası ise, görüşme öncesi projeyi, amaçlarını, kapsamını anlatmayı, katılımcıların evlerine ya da işlerine giderek onlarla sohbet etmeyi, dolayısıyla bir süreci gerektirir. Araştırma projesi kapsamında görüşme yapılacak yüz görüşmecinin vaat edilmiş olması, bu araştırmada bizler için zorlayıcı bir etkendi. Zira güven ilişkisi kuracak denli sahada onlarla geçirecek çok vaktimizin olmayışı, görüşmeci arayışını, öncelikle yakın çevremizden başlatmamıza yol açtı. Ebeveynlerimizden, ders aldığımız hocalarımıza, komşularımızdan film festivallerinde görüp, bazen konuşmadan selamlaştığımız sinefillere, ders verdiğimiz kurumlardaki öğrencilerimizin ailelerinden çalışma alanlarımızdaki meslektaşlarımıza değin yakın çevremizdekiler, ilk görüşmecilerimiz oldular. Onların da araştırmayı arkadaşlarına, tanıdıklarına anlatmalarıyla görüşmeci kaynağımız zenginleşti. $\mathrm{Bu}$, araştırma literatüründe kartopu örneklem olarak tanımlanan bir örneğe de uymaktayd1. Ancak böylesi bir seçimin, görüşmecilerin belli bir sosyal katmanda yoğunlaşmasına neden olduğunu da belirtmeliyim. Kendi çevremizden seçerek erişmeye çalıştığımız görüşmecilerin/ kaynak kişilerin, eğitimli, belirli bir gelir düzeyinin üzerinde, orta ve orta-üst sınıftan olmalarıyla, elde ettiğimiz sinema deneyimi de kimileyin seçkinci, akademik oldu. Bu durum, özellikle Ankara ve İstanbul'da belirgin hale geldi. Yalnızca üniversitede öğretim üyesi olarak çalışan 10’u aşkın katılımcımız olmuştu. Sosyal sınıflar anlamında oluşan bu dengesizliği, diğer kentlerdeki görüşmeci seçimleri ile dengelemeye çalıştıysak da, bunda çok başarılı olduğumuz söylenemez. Orta ve üst sınıflardaki bu yoğunlaşmada, daha düşük gelirli ve daha az eğitimli görüşmecilerin, zaten daha az sıklıkla sinemaya gitmiş olması ve bu görüşmecilerin kendi deneyimlerini 
anlatmaya değer bulmayışlarının da etken olduğunu iddia edebiliriz. Kendi yaşadıklarını sıradan olarak niteleyerek anlatmaya değer bulmamak, tam da sözlü tarihin görüşmelerinde aşılması gereken engellerden biridir. Görüşmeci bulma sürecinde birkaç aday, bu nedenle görüşme yapmak istemedi ve ne yazık ki onları görüşmeye dâhil edemedik.

Orta-üst sınıf ve eğitimli görüşmecilerimiz için ise, başka bir sorun söz konusuydu. Fikir vermesi, anımsatıcı olması için (çoğu kez katılımcıların da kendi istekleriyle) önceden gönderdiğimiz görüşme soruları, bazı görüşmecilerimizde aşırı hazırlık yaparak, neredeyse soru sormadan, formdaki tüm konulara dair bir aktarımı beraberinde getirmişti. Sözlü tarihin doğasına uygun olarak konuşma sırasında gereksiz müdahalelerle anlatıyı kesmemek icap etse de, böylesi bir durum, araya girmemizi zorlaştırd1, ayrıntılandırılması gereken yerler konusunda daha dikkatli olmaya sevk etti. Örneğin ilk kaynak kişimiz ve hocamız olan Seçil Büker (1947, Eskişehir), ${ }^{1}$ bir sinema akademisyeni olarak soruları önceden görmüş ve hazırlanmıştı. Onunla yaptığımız ilk görüşmeden, gerek araştırma sürecine gerekse araştırmacı olarak konumumuza ilişkin bir farkındalıkla çıkarak yolumuza devam ettik.

Görüşmelerin başlangıcında yaşadığımız bir deneyim de, "katılımcılara araştırmanın amacı, süreci, beklenen olası riskleri ve yararlarını ifade eden, rahatsız oldukları ya da istemedikleri anda görüşmeden özgürce çekilme hakları olduğu bilgisini veren bilgilendirilmiş rıza formu" (Thorne, 1980: 285) ekseninde ortaya çıkmıştı. Bu formu, araştırma projemin finansal ve bilimsel destekleyicisi TÜBİTAK’a vaat ettiğim üzere, çalıştığım İstanbul Üniversitesi Bilimsel Araştırma Birimi’nin öngördüğü çerçevede ki esasen sağlık araştırmaları alanındaki etik sorunlar temelinde hazırlanmıştı- katılımcılara imzalatmak zorundaydım. Araştırdığım konu, sinema anıları gibi, nispeten keyifli bir alanı çağrıştırıyordu, ancak imzalanması gereken bu formun, katılımcılarda çekinceye yol açtığını gözlemliyordum. Zira bu form, keskin biçimde katılımcılara benim araştırmac1 konumumu, üzerime yerleştirilmiş kurumsal ve resmi devlet ağırlığını bariz biçimde vurguluyordu. Bir çeşit sözleşme olan bu formda yazılan ifadeler, az sonra yaşanacaklar konusunda katılımcıları kaygılandırabiliyordu. Sinemadan konuşurken, rahatsız edici ne olabilir ki? Görüşmelerin başlangıç anlarında beliren bu kaygının, süreç ilerlediğinde kaybolduğunu, ancak formu imzalama anında tekrar bir çekince duygusunun ortaya çıktığını gözlemledim. Esasen sağlık bilimleri alanında ve pozitivist araştırma tasarımı temel alınarak hazırlanan bilgilendirilmiş rıza formlarının, sözlü tarihin doğasına uygun olmadığını, katılımcıların bedensel, zihinsel ve duygusal olarak korunmalarını taahhüt eden nitel araştırmanın doğasına uygun başka etik düzenlemeler gerektiğini düşünüyorum.

\section{Güç ve yardımlaşma ekseninde araştırmacı-katılımcı ilişkisi}

Pozitivist araştırma paradigmasının sorgulandığı günümüz etnografik araştırma sürecinin odağında araştırmacı özne ile onun bilgiyi üretme ve yazma süreci bulunur. Crick, antropoloğun topluluk hakkında gözlem yapıp bunları kuramsal kıstaslara uyarlamaya çalışırken, topluluk üyelerinin de süregelen olaylar ve durumlara anlam empo- 
ze ettiklerini; bunu yaparlarken de genellikle antropoloğun tutum, tavır ve davranışları hakkında gıyabında yaptıkları spekülasyonlardan hareket ettiklerini (1982: 25'den akt, Atay, 2017: 199) belirtir. Bu, sahada bilginin tek sesli değil, çok sesli diyalojik olarak üretildiğini ortaya koyar. Etkileşim ürünü olan bilgi, "farklı öznelliklerin paylaşıldığı ve etkileştiği “öznelerarası” (intersubjective) bir bilgi alanıdır” (Tedlock, 1991: 71).

Etnografik araştırma literatürü, araştırmacının varlığının, araştırılan konu ya da nesne üzerindeki etkisinin bilinmesi gerektiğini söyler. Zira "etnografik anlatı, etnograf/ antropolog ile incelediği topluluk arasındaki güç/iktidar ilişkilerinin niteliğinden etkilenir” (Atay, 2017: 197). Araştırmacı, sahada çoğu kez, bilimsel/ akademik/ kurumsal bir göz, bir fail, bir bilen olarak denetim ve gücün sahibi olarak algılanır. "Antropoloğun gücü, üzerinde çalıştığı topluluğun 'bilinmesini sağlamak’tan kaynaklanır (Atay, 2017: 196). Bu güç, onu bilen özne, araştırılan konu ya da grubu da, bilgisi sınananlar olarak eşitsizce böler. Araştırma sürecinde araştırmacıya atfedilen "bilgili” rolünün inşasında ya da yıkılmasında, bizatihi araştırmacının konumu ve performansı da etkilidir. Örneğin araştırma projemiz çerçevesinde çoğu görüşmecimiz, üniversiteden geldiğimizi, araştırmanın TÜBİTAK tarafından desteklendiğini öğrendiklerinde, araştırmacı olarak bizleri de devletin bir temsilcisi, bir faili, resmi gücün bir uzantısı olarak görmekteydiler. Bizler araştırmacı olarak bir şey yapmasak da, araştırmacıya atfedilen rol, devletin resmi otoritesinin ağırlığını taşımaktaydı. Bilme hakkını ve gücünü, her şeyi denetlemek isteyen devlet ve onun ordu, okullar, hastaneler gibi kurumsal aygitları elinde tutabilirdi ne de olsa! $\mathrm{Bu}$ durumda görüşmecilerin anlatılarını kısıtlayarak bize sunmaları dikkat çekiciydi. Bizlerin iradesi dışında resmi olarak kurulu devlet söyleminin bir bileşeni olarak araştırmacıya atfedilen ve onu kimliklendiren kavrayış, örneğin Antakyalı bir seyircinin, kentin çok kültürlü, çok inançlı, çok kimlikli yapısı olduğunu anlatırken hissedilebiliyordu. Antakya'nın Nusayri, Ermeni, Hristiyan Arap bileşenleri, katılımcının anlatısında rahatlıkla dile getirilemiyordu. Zira etnisitenin rahat konuşulabildiği bir tarihsel dönemde olduğumuzu söylemek pek mümkün değildi. Çünkü etnisite, resmi söylemin her türlü bütünlügüne bir tehdit gibi algılanır. Politik olarak çalkantılı dönemler bu algıyı daha da güçlendirir. Hatta resmi olarak benimsenmiş tek millet kavrayışı, diğer etnisitelerden birinden olmayı neredeyse suç sayar. Görüşme yaptığımız dönem, tam da böylesi bir döneme denk geldiğinden, katılımcıların, anlatılarına çeki-düzen vermek zorunda kalmaları anlaşılabilirdi.

Görüşme süreci ilerlediğinde, araştırmacı ve katılımcılar arasındaki hiyerarşi, pek çok açıdan değişmeye başladı. Bilgi ve güç ilişkisini akla getiren, bazı katılımcıların anlatılarını, "Öyleydi, değil mi?" diye bize/ bana onaylatma çabaları, süreç içinde görüşmecilerin deneyimlerine dair anlatılarının zenginliği ile, onları daha etkin ve bilgi öznesi kılan bir sürece evrildi. Böylece görüşmelerden oluşan etnografik araştırma süreci, bir grubun kültürünü (sinemaya gitme kültürü) ortaya koyarken, araştırmacı ve araştırılan arasındaki etkileşimlerin, "farklı öznelliklerin paylaşıldığı ve etkileştiği "öznelerarası" (intersubjective) bir bilgi alanına, katılımcı gözlemden katılımın gözlemlenmesine dönüşmeye (Tedlock, 1991: 71-79) başladı. Bu diyolojik bilgi alanı oldukça değerlidir. 
Clifford'a göre (1988'den akt. Peace, 1990: 21 'den akt. Atay, 2017: 199) “etnografik etkinliği bir diyalog ve antropolog ile topluluk üyeleri arasında bir etkileşim olarak kavrayan 'diyalojik etnografi', hem bir etkinlik hem de süreçtir. Bu süreç, asgari düzeyde 'deneyim'in yazıya çevrimi olup çok yönlü öznelliklerin etkisi ve yazar/antropoloğun kontrolü dışındaki politik kısıtlamalara bağlı olarak daha karmaşık bir hale gelir”.

Tedlock (1991: 77), araştırmacının, incelediği kültür ile birlikte kendisini (kendi ilişkisini de) anlattığında bir türsel değişim de yaşandığını söyler ve bunu etnografik anıdan (memoire), anlatısal etnografiye bir tür değişim olarak tanımlar.

"Etnografik anı yazarında, bir yazar bizi olağandışı etkileyici veya benzersiz olaylarla çevrili olan kendi yaşam alanına geri getirir. Objektifi daraltarak, bu yazarlar sahadaki kişisel hayatlarına, tam boy bir otobiyografide mümkün olmayacak bir pencere açarlar. Bir anlatı etnografisinin yazarı da deneyimlerle ilgilidir; ancak bunlar etnografik veriler, saha çalışması katılımı ve kültürel analiz üzerine epistemolojik yansımalar ile uzun süredir devam etmektedir. Anlatısal bir etnografide dünya, yerli bir anlatıc1 tarafından algılandığı gibi yeniden sunulur ya da hikâyede kendi kişiliğini ortaya koyan bir karakter olarak varlığını sürdürür. Bu okura, metin içinde seçilmiş, biçimlendirilmiş bilinçle özdeşleşmesini sağlar. Anıların tersine anlatısal etnografi, etnografin kendisine değil, daha çok etnografik diyolog ve etkileşim sürecine ve karakterine odaklanı" (Tedlock, 1991: 77-78).

$\mathrm{Bu}$ düşünümsel süreçte artık, araştırmacının da araştırılan için kim olduğu sorusu önemli hale geldiğinde, araştırmacının cinsiyeti, sınıfı ile diğer aidiyetlerinin araştırma sürecinde belirgin etkileri fark edildi. Bu farklar ya da kimlikler, etnografik yazıma da taşındı. Böylece Tedlock’un da vurguladığı gibi (1991: 81-82). "etnografik yazım, 'ben' ve ‘öteki' diyaloğu ve etkileşimi çerçevesinde biçimlendi. "Antropolojide özdüşünümsellik, bu diyalojik etnografik etkinlik sürecinde edinilen deneyim üzerinde bir derin ve dikkatlice düşünme önerisidir" (Atay, 2017: 200).

"Bu noktadan hareket eden bir antropolog incelediği "dünya"y1, kendisinin de bir parçası olarak içerisinde yer aldığı ve kendi şahsiyetini de açığa çıkaran bir anlatı (narrative) çerçevesinde takdim eder. Bunun içinde klasik anlamda etnografik malzeme veya verilerin yanı sıra alan çalışmasındaki katılımı üzerine antropoloğun epistemolojik düşünceleri de yeralır" (Tedlock, 1991, s. 77).

Sinemaya gitmeye dair araştırmamızda araştırmacı kimliğimi sarmalayan duruşların ve aidiyetlerin etkili olduğunu görmek, tam da böylesi bir duruma karşılık geliyordu. En küçüğü 50, en büyüğü 90 yaşında olan görüşmecilerle aramızdaki yaş farkı, onlara "Sizler sanırım bilmezsiniz" ile başlayan cümleleri kurdurabiliyordu. Ancak görüşme sürecinde anımsamaya çalıştıkları sinemaya dair bazı bilgileri veriyor olmam, tekrar beni bilen bir özne olarak konumlandırıyordu. Bilmediğim ve merak ettiğim şeyin, bizatihi onların kendi deneyimleri olduğunu, çok değerli olan bu deneyimlerin mutlaka kaydedilmesi gerektiğini anlatırken buluyordum kendimi. Bunun, katılımcıların anlatma 
şevkini artırdığını fark etmiştim. Peki ye diğer aidiyetlerimin, kimliklerimin araştırma sürecinde rolü neydi? Bunu, süreç içinde sahada öğrenmeye devam edecektim.

\section{Performans olarak deneyim}

Summerfield, sözlü tarihin, seyircinin kendilik/ benlik üretiminde anahtar bir rolü olduğunu söyler. "Görüşülen özneler, kendilerini kamusal bir birlik olarak kavrar ve inşa ederler" (Summerfield, 1998: 20'dan akt. Tomsic, 2005: 2). Ona dayanarak Mary Tomsic de (2005: 2), öznelerin, onların semt tarihlerinin parçasını temsil eden anılarının kaydedildiğinin ve sonra ona kamunun erişebileceğinin farkında olduğunu söyler. Bu saptamalar, sözlü tarih görüşmelerinin, performans çerçevesinde incelenebileceğine işaret eder. Araştırmamızda katılımcılarımızla yaptığımız bilgilendirme görüşmelerinde, bu görüşmenin bir belgesel filmde ve sergide kullanabileceği bilgisi verilmişti. Bu bilgi, katılımcılarda daha dikkatli konuşmaya çalışma, daha iyi görünme gibi bir çabayla tanımlanan bir performansta etkili olmuştu. Zira kameranın varlığı, görüşmecinin ve benim araştırmacı olarak davranışlarını etkileyerek, görüşmenin doğasını etkileyecek bir niteliğe sahipti. Hatta belgesel film gibi kamunun erişimine açık bir üründe görünür olmak, bazı katılımcılarımızda öylesine kaygıya neden olmuştu ki, İstanbullu görüşmecimiz Hülya Avkın (1955, Gaziantep), sesinin iyi olmadığı gerekçesiyle başlangıçta görüşmeye katılmak istemedi ve bu konuyu, çalıştığım okuldaki odama gelerek konuştu. Araştırmacı olarak benim sahada bulunmam gerekirken, Hülya Hanım benim sahama girmeyi istemesi, bana, katılımcıların da sahayı, farklı yönleriyle tanıma ve bilme hakları olduğunu düşündürdü. Nihayet görüşmeye ikna olan Hülya Hanımın ofisinde buluştuğumuzda ise, araştırma bursiyerimiz Arda Kaya'nın varlığının, onda farklı bir rahatlama yarattığını fark ettim. Arda'nın fiziksel görünümü, görüşmecimizde bir sempati yaratmıştı, çünkü Hülya Hanımın damadı ile aynı şehirli idi. Fiziksel görünümün ve sosyo-etnografik aidiyetlerin katılımcılarda yarattığı etkiyi görmek, düşündürücüydü. İstanbul'da yaşayan, aksansız konuşan erkek bir sinema akademisyeni, araştırmacı olarak konumum, elbette farklı katılımcılarla değişebildi, farklılaştı. Dorninne Kondo'nun söylediği (1986: 74) gibi etnografik süreçte araştırmacı olarak benliğim, aidiyetlerime dair farklı kavrayışlar nedeniyle bölündü ya da tekrar inşa edildi. Zira çoğu etnografya, düşünümsel türde bile olsa, gözlemcinin / etnografin görünür bir yabancı olduğu bağlamların ürünüdür (Kondo, 1986: 74).

\section{Kayıp geçmiş nostaljisi}

Saha çalışmamızda geçmiş sinema deneyimlerini anlatırken katılımcıların neredeyse tamamının geçmişi büyük bir özlemle andıklarına, görüşmelerin kayıp geçmişe dair bir nostalji ürettiğine tanık olmuştum. Sinemaya gitme anlatıları, katılımcıların deneyimlerini şimdi ve geçmiş kavram çifti bağlamında hikâye ettiğini, bu hikâyelemede geçmişin "her şey güzeldi" söylemiyle üretilen nostalji duygusunun egemen olduğunu ortaya koyuyordu (Akbulut, 2016). Geçmişe özlem duyan nostaljik bakış, öznelerin izledikleri filmleri ve sinemaya gitme deneyimlerini ayrıcalıklı hale getirdiği gibi, kendilerini de 
bu ayrıcalıklı deneyime tanık olmuş "ayrıcalıklı" özne konumu veriyordu. Bu nedenle izledikleri filmler, eksik teknolojiyle yapılmış olsalar da, onlara daha değerli ve sahici görünüyordu. Onların tanık olduğu hayat, daha sıcak, samimi, gerçekçi, toplumcu ve ideolojiden arındırılmışlık anlamında "saf" iken, şimdiki hayat ve sinema, daha yapay, soğuk, bireyci ve "ideolojik"ti (Akbulut, 2016: 249-250). Onlar geçmişi, sinemaların, tiyatroların, operaların olduğu, sokağa çıkan insanların giyim- kuşamlarına ve davranışlarına dikkat ettikleri, nezaketin, sevgi ve saygının olduğu, ortaklaşmacı zamanlar olarak betimliyorlardı ve bu geçmişi anlatırken gözleri ışıldıyor, yüzleri gülüyordu. Ardından "O zamanları çok özlüyorum." cümlesiyle kayıp geçmişe özlemlerini ifade ediyorlard. 1975 'te doğmuş, Yeşilçam dönemini sinemalardan izleme olanağına kavuşamamış olan ben, her ne kadar geçmişin hikâye edilmesinde unutulanlar, gizlenenler, dile getirilmeyenler ve abartmalar olduğunu bilsem de, katılımcıların anlatılarından etkilenmiş ve o dönemde yaşamayı istemiştim. "Nostos (eve dönüş) ve algia (özlem) sözcüklerinin birleşiminden oluşan nostalji, artık var olmayan veya hiç var olmamış bir eve duyulan özlemdir" (Boym, 2009: 14) ve sözlü tarih görüşmelerinde belirgin biçimde ortaya çıkan bir duygudur. Çünkü kişiler geçmişlerine bugünün koşullarıyla bakarlar ve geçmişi yeniden inşa ederler. Halbwachs'ın da belirttiği gibi (2016) anımsama, şimdinin bakışıyla geçmişin kurulmasından başka bir şey değildir. Görüşme yaptığımız katılımcılardan biri olan Oğuz Onaran'ın (1935, İzmir) 1960'ları, “Türkiye'nin rönesansı" olarak tanımlamasının ardında da bu etmen vardı. Katılımcıların tanıklık ettiği ve sinemaya gitmeyi deneyimlediği bu tarihsel dönem, pek çoklarına göre daha adil ve demokratik bir anayasa ile toplumsal, ekonomik ve kültürel gelişmenin/ kalkınmanın resmi olarak benimsendiği yıllardır. Eğitim ve kültüre verilen önem, neredeyse tüm şehir ve kasabalarda, hatta mahallelerde açılan sinemaların varlığıyla somutlanmıştır. Pek çok katılımcının ifade ettiği gibi, o yıllar, insanların toplumsal ve kültürel modernleşmeyi sinemalardan öğrendiği bir dönemdir. Çalışmanın yapıldığı dönemin Türkiye'si ise, sineması, tiyatrosu, kitapçısı olmayan şehirlerin olduğu, sinema salonlarının küçültülerek AVM'lere hapsedildiği, sıcak, samimi ilişkilerin ve dayanışmanın mekânı olan mahallelerin yerini soğuk, mesafeli ilişkilerin ve kayıtsızlığın egemen olduğu çok katlı beton yapıların aldığı, kültürel modernleşme çabalarının bir bir terk edildiği bir dönemini yaşıyordu. Katılımcıların anlatıları, büyük oranda onların sinemayı, kültürel modernleşmenin ve Cumhuriyet Türkiye'sinin, aydınlanma idealinin bir parçası olarak kavradığını ve deneyimlediğini, bu deneyimden de haz aldığını gösteriyordu. Bu, onların şimdiki döneme ve koşullara daha karamsar bakmalarına ve gelecekle ilgili kaygılanmalarına da neden olmaktaydı. Zira Huyssen'e göre "yarından umudun kesildiği gün, modernliğin de ipi çekilmiştir" (1999). Çağdaş bir Rus deyişine göre geçmiş, gelecekten çok daha tahmin edilemez hale gelmiştir. Nostaljinin temelinde bu tuhaf tahmin edilemezlik yatar" (Boym, 2009: 14). Tam da bu nedenle katılımcıların anlatılarında, yüz ve bedenlerinde beliren bu nostalji duygusu, bir araştırmacı olarak beni de sarmalamıştı. Sahadan sonra masa başında hissettiğim şeyin nasıl bir nostalji olduğu üzerine düşündüm.

İki anımsama eğilimi arasında ayrım yapan Boym'a göre bir yanda yeniden kuru- 
cu nostalji, diğer yanda ise düşünsel nostalji vardır. "Yeniden kurucu nostaljide vurgu, nostos’tadır ve yitirilmiş evi yeniden inşa etmeyi ve hafızadaki açıkları kapatmayı vaat eder. Düşünsel nostalji ise, algia’ya, özlem ve yitirmeye, hatırlamanın kusurlu sürecine yoğunlaşır... Yeniden kurucu nostalji geçmişten kalma anlatıların bütünsel yeniden inşasıyla tezahür ederken, düşünsel nostalji başka bir yerin ve zamanın hayali içinde yıkıntılarla, zamanın ve tarihin pasıyla uğraşır" (Boym, 2009: 76, 77). Sinema deneyimi ile kaynak kişilerde ve bende ortaya çıkan nostalji, bu iki eğilimi de içinde barındırıyor görünse de, temelde düşünsel nostaljiye denk geliyordu. Yeniden kurucu nostalji, saplandığg geçmişi yeniden inşa etmeye çalışırken, kökenlere dönüş ve komplo teorisi gibi aşırı sağcı politikaları da üretir. Oğuz Onaran'ın o yılları “Türkiye'nin rönesansı” olarak tarifi, "geçmişin kusursuz bir enstantane olarak üreten yeniden kurucu nostalji” (Boym, 2009: 87) gibi görülse de, 1960’lı yılların kültürel canlılığını ve saygınlığını özleyen bizler, o günleri şimdide inşa etmeye çalışmıyorduk. Bizlerin hafızasını tetikleyen pratik, sinemaya gitmek olsa da, odaklandığımız, bireysel ve toplumsal hafıza, işbaşında olanın düşünsel nostalji olduğunu gösterir. "Düşünsel nostalji, ayrıntıları ve hatırlama işaretlerini önemseyen bireysel anlatıya meyleder; hafizanın parçalanmış fragmanlarından hazzeder ve mekânı zamansallaştırır. İronik ve mizahi olabilir" (Boym, 2009: 88). Özlem duyulanlar, bireysel olarak anımsamalarda tek tek açığa çıkar. Bu açığa çıkarma ile sinema anılarının da belgelenmeye ve incelenmeye değer bir deneyim olduğunu katılımcılara anımsatır.

Deneyimlenmemiş bir geçmişin özlenmesi ve de anımsanmasına postmemory kavramıyla da bakmak mümkündü. "Bir öznenin başkalarından dinlediği, kendisinin yaşamadığı yakın geçmişteki olayları anılara dayanarak belleğinde yeniden inşa etmesi” (Hirsch ve Young'dan akt. Sarlo, 2012: 82) anlamına gelen postmemory, Young'un tanımladığ1 gibi vekâleten bir deneyimdir. Yaşanmamışı, "vekâleten” hatırlatan şey, aile, okul gibi çevreden ara ara gelen uyaranlardır. Kaynak kişilerin anlatılarının, sinemayı tarihsel ve kuramsal olarak çalışmakta olan benim için, böyle bir postmemory olduğunu fark etmiştim.

Marianne Hirsch (2001: 8), İkinci Dünya Savaşı sırasında Nazi Almanya’sının Holocost deneyimi çerçevesinde yer verdiği postmemory kavramını, kuşakların bellek ve travmaya verdiği tepkiler, daha özelde ise, ikinci kuşağın birinci kuşağın travmasına verdiği tepki olarak okur. "Postmemory, özgün biçimde, hayatta kalanların kültürel veya kolektif travma çocuklarının ebeveynlerinin deneyimleriyle olan ilişkilerini tanımlar. $\mathrm{Bu}$ deneyimler yalnızca onlarla büyüdükleri anlatılarda ve imgelerde "anımsansa" da, kendi başına anılar oluşturacak kadar çok güçlü, çok anıtsaldır” (Hirsch 2001: 9). Travmatik deneyimi yaşayan ilk kuşağın anlattıklarıyla büyüyen ikinci kuşak için bu anılar, korkutucu bir deneyim olarak hatırlanır. Sinema örneğinde de ikinci kuşağın bir üyesi olarak benim 60'lı ve 70'li yılların sinema kültürüne dair belleğim, yaşayarak edindiğim olaylarla değil, okuduklarım ve ilk kuşağın deneyimlerinin anlatısıyla kurulmuştu. Böylece sözlü tarih görüşmeleri, benim için 60'l1 ve 70'li yılların sinema kültürünü yeniden kurarak, postmemory işlevi görmüştü. O yılları yaşayan ilk kuşak gibi her firsatta mahallemizde gidebileceğimiz bir sinemamız ve kimine göre ucuz bir eğlence, kimine 
göre modern, kentli, eğitimli ve kültürlü bir yurttaş olmanın öğrenildiği ya da pratik edildiği, ritüelleri olan sinemaya gitme deneyimim olmamıştı. Solumayı istediğim o dönemi anlatan katılımcılar, bu nedenle, Arda'nın söylediği gibi gözümüze film yıldızı gibi görünmeye başlamıştı. Aşağıda açıklanacağı gibi, görüşmelerden oluşturduğumuz fotoğraf sergisi ve video film, bu kavrayışımızı pekiştirmişti.

\section{Saha deneyimini yazmak: Yazıya karşı fotoğraf ve film}

Sinema deneyimine dair araştırma sürecinde, saha çalışmasını, sahadan aldığım notlar, kuramsal okumalar ve çıkarımlarla birlikte sürdürmeye çalıştım. Evet, görüşmelerin yapıldığ "saha" ile araştırma raporunun yazıldığ "ev" ayrıdd, ama bir yıl boyunca haftalık çalı̧̧ma zamanımı, bu ikisi arasında bölerek planlamaya çalıştım. Görüşme bitiminde, eğer şehir dışında değilsem, doğrudan eve dönüyor ve aldığım notları düzenliyor, görüşme anlatıları üzerine düşünüyordum. Her görüşmenin kendi içinde bütünlüğg̈ ve özgünlüğü vardı. Akademik ve bilimsel analizler için görüşmeleri parçalamaksızın, görüşme ortamının sıcaklığını, samimiyetini, duygularını aktarmak/ temsil etmek istiyordum. Sahada araştırmacı olarak bizlerin ve katılımcıların etkileşimi ile ortaya çıkan duyguları ve deneyimleri, Marcus ve Fisher'in de belirttiği gibi (2013) yazıdan çok görsel ve işitsel ürünler daha iyi temsil edebilirdi. Araştırma projemde vaat ettiğim gibi görüşmecilerden elde etmeyi umduğum görsel ve yazılı belgelerden (resim, fotoğraf, afiş, bilet, günlük, poster vb.) oluşacak olan sergi ile film, bunu olanaklı kıldı. Görüşmecilerden elde ettiğim malzemeler, bir sergi için yeterli olmasalar da (çünkü çok az görüşmeci sinema deneyimlerine ilişkin belge ve malzeme saklamıştı), Arda ile birlikte yazılı, basılı ya da dijital pek çok kaynağı, mecrayı tarayarak, görüşmecilerin sinema anlatılarında aktardığı filmlere, sinema salonlarına, oyunculara dair görsel malzeme edindik. Belirli temalar ve kategoriler ekseninde görüşmecilerin anlatılarından seçtiğimiz ifadeleri, onların görüşme sırasında çektiğimiz fotoğrafları ve görsel malzemeler eşliğinde fotobloklara bastık. Sergimizin temel malzemesi, bu fotobloklard1. Video filmimizin hammaddesi ise, videoya kaydedilmiş görüşmelerdi. Görüşmelerin video kayıtlarını da, sergide olduğu gibi farklı malzemelerle harmanlayarak 30 dakikalık bir film hazırladık. Serginin adı, "Belleklerdeki Sinema: Seyircinin Sergisi" idi, filmin adı ise "Belleklerdeki Sinema". Bu isimler, o zamana dek filmlerin seyircileri olmuş öznelerine, şimdi başrol veriyordu. Sergi ve film, katılımcıların belleklerindeki sinemayı betimlemeye çalışıyordu. Zamansal, mekânsal ve maddi sınırlıklar nedeniyle 100 görüşmecinin deneyimine ne yazık ki yer veremedik, Ayrıca her deneyimin kendi özgünlüğü içinde kalması ve öyle yorumlanması gerektiğine inansak da, sergi ve film, farklı yaş ve sosyo-demografik katmanlardan görüşmecilerin sinema deneyimlerinin genel bir ortalamasını sunma ya da bazı "daha dikkat çekici/ zengin" anlatıların temsil edilme, daha olağan ve "rutin" anlatıların ise gözden kaçırılması çıkma riski içeriyordu. Bu risklere karşın sahanın deneyimini, seslerini ve duygularını bir ölçüde temsil edebildiğimizi düşünüyorum.

Ankara'da 23. Uluslararası Ankara Film Festivali kapsamında, Goethe Enstitüsü 
Ankara'da (Alman Kültür Merkezi) 21 Nisan-6 Mayıs 2017 tarihleri arasında açtığımız Belleklerdeki Sinema: Seyircinin Sergisi ve aynı başlıklı video film, sahanın deneyimlerinin daha sıcak, samimi atmosferini temsil ederken, bir yandan da görüşmecileri, kahramanlaştırıyordu. Sinemaya her firsatta giden ve onu hayatının temel bir parças1 olarak gören sinefiller Ayşe Çı̆̆g, Gönül Hatay Eren; bir Ediz Hun'cu olarak yıldız hayranlığını anlatan Necla Oktay; doğduğu Balkanlardan İstanbul'a göçerek yeni bir hayat kuran ve Beyoğlu'ndaki sinemaları büyük bir hayranlıkla betimleyen Fevzi Disan11; Çorum'da gittiği Yeşilçam filmleri üzerine o dönemlerde neler konuştuklarını büyük bir tatlılıkla anlatan Emine Uçar ve daha nice görüşmecimiz bizler için artık bir yıldız olmuştu. Onların anıları, öylesine büyüleyici idi ki, bu hayranlık, "katılıma odaklanma ve yakınlık kurduğum grubun bireylerinin bakış açılarıyla özdeşleşerek beliren yerlileşme eğilimi” (Nahya ve Rahmanşah, 2016: 21) araştırmacı olarak onların anlatılarına göstermem gereken analitik çerçeveyi kimileyin öteliyordu. Biraz yerlileşmek (going native), katılımcılarımızı benim gözümde/ bizim gözümüzde Türkân Şoray gibi, Tarık Akan gibi yıldızlaştırıyordu. Bu duyguyla artık onlar, araştırma sürecine katılmış sinemayı seven bir topluluk değildi, duygularına ortak olduğum, neredeyse jest ve mimiklerini taklit edebileceğim yüz oyuncuydu. Elbette görüşme sürecinde daha yakın ilişkiler kurarak çoktan veri kaynağı olmanın ötesine geçmiş katılımcılarla ilişkilerimiz daha da değişmişti. Sergi ve film hazırlığı süreci, katılımcıları, onların anlattıkları aracılığı ile bir takım çıkarımlar yapacağım veri kaynakları olmaktan çıkararak, hayat öykülerini, özlemlerini, kırgınlıklarını, ailelerini tanıdığım, onlarla birlikte üzülüp sevindiğim bir tanıdığa, bir arkadaşa, bir sırdaşa dönüştürmüştü. Saha çalışmamız bitmesine karşın onlarla haberleşmeye, selamlaşmaya devam ederek ilişkilerimizi sürdürüyoruz. Bu süreçte edindiğim bilgi, Hastrup'un ifade ettiği gibi (2004: 457) hem ilişkiler yoluyla edinilmiş işbirlikçi, diyalojik olması anlamında hem de araştırmacı ile inceleme konusu (nesnesi) arasındaki ilişkinin, nesnenin kendisinin bir özelliği olması anlamında ilişkiseldi.

\section{Perdede kendini seyreden seyirci}

Tüm araştırma ekibimiz ile Ankaralı bazı görüşmecilerimizin katıldığı bu sergi, film festivali kapsamında, Yeşilçam’ın jön oyuncusu İzzet Günay’ın katılımıyla açıldı. Görüşmecilerimizden bazılarının hayranı olan İzzet Günay’ın katılımı, bizler için olduğu kadar, açılışa gelen konuklar ve seyirciler için de oldukça önemliydi. Konukların çoğu, Vesikalı Yarim'deki performansıyla belleklerde yer eden Günay ile fotoğraf çektirmeye, onunla konuşmaya çalışıyordu. Perdede seyrettiği yıllarda onunla böylesine yakın bir ilişki kurmamış seyirciler için İzzet Günay, şimdi kanlı canlı olarak karşılarındaydı. Bu unutulmaz an, hayranlık deneyimini tekrar düşünmeye firsat verdi. Katılımcıların bizlerle fotoğraf çektirmek istemesi, bizleri de bir anlığına film yıldızlarına benzer kılıyordu, ancak sahnede olması gereken onlardı. Sergi ve film gösterimi ile birlikte araştırma süreci, katılımcıların kendilerini gözlemlediği, değerlendirdiği bir sürece olanak verdi. Foto bloklarda ve video filmde kendilerini seyreden katılımcıların konumu, görüşmeciden, kendilerinin seyircisi olmaya doğru değişmişti. 


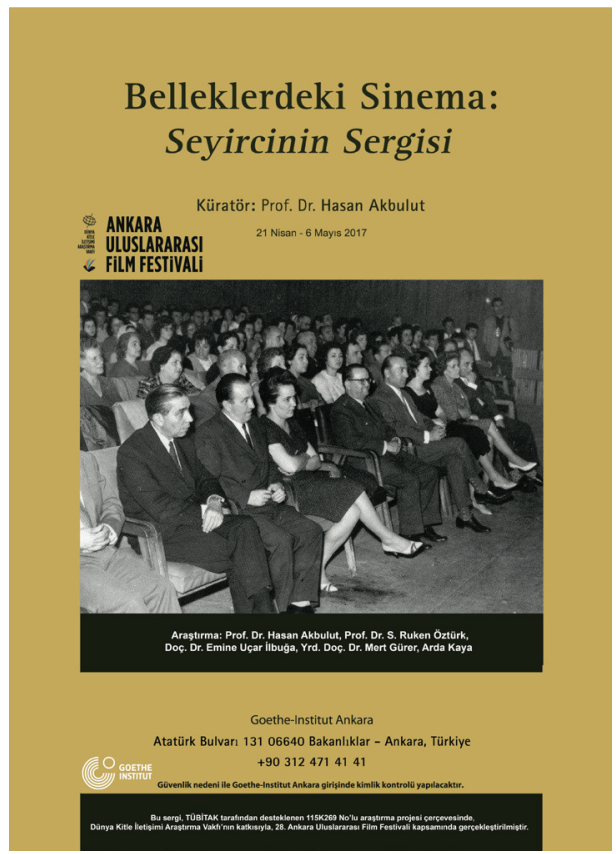

Yeter Beriş tarafından hazırlanan sergi afişi.
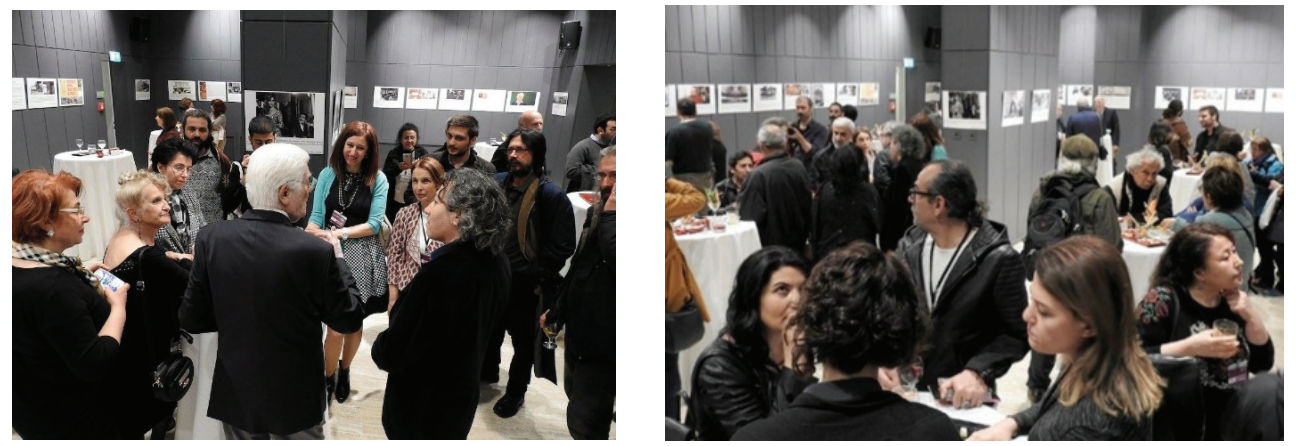

Sergi açılış kokteyli: Katılımcılar, araştırmacılar ve yıldız oyuncu İzzet Günay 

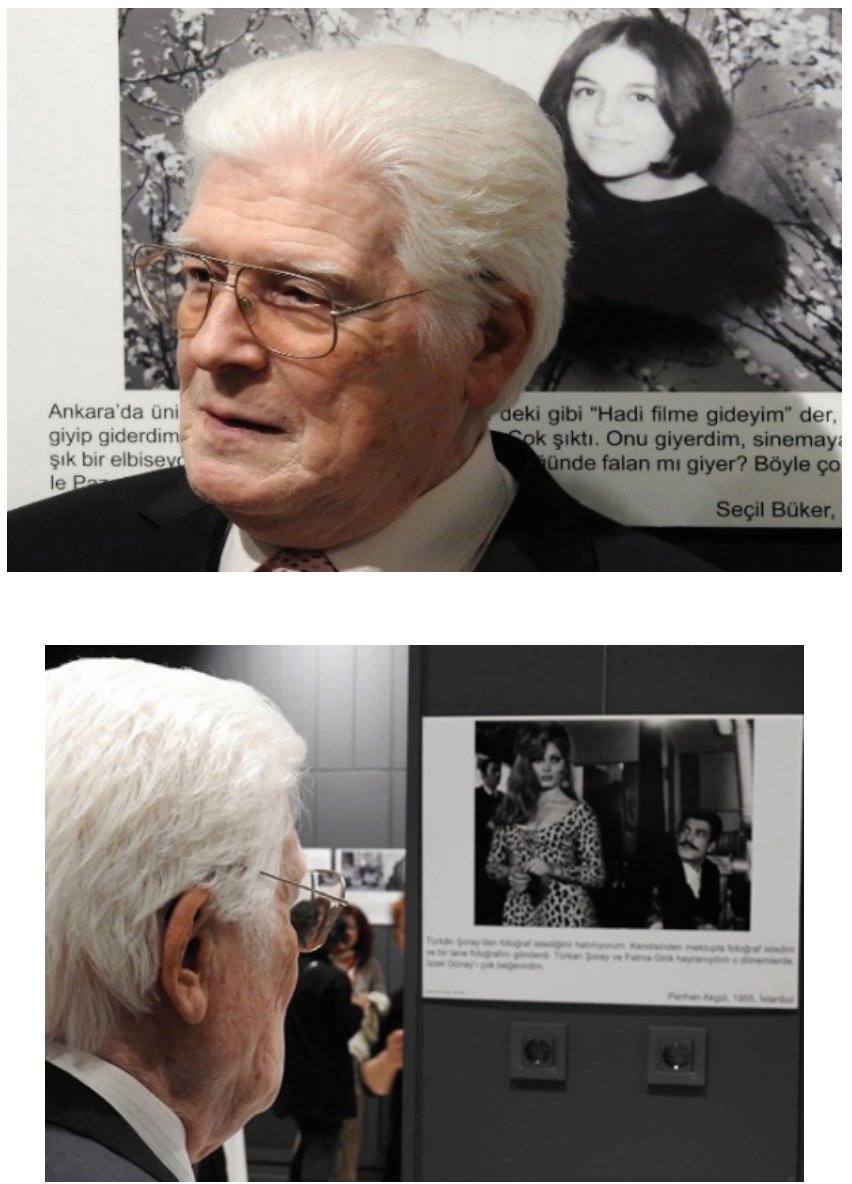

İzzet Günay, Vesikalı Yarim'de kendisine bakıyor.

Fotoğraf Kaynağı:Uluslararası Ankara Film Festivali

Aynı gün sergi açılışının ardından, Belleklerdeki Sinema adlı video filmimizi seyircilerle buluşturduk. Bu, bizler için oldukça heyecanlı ve ikilemli bir süreçti. Öncelikle her biri özel olan 100 görüşmenin, bu video filmde temsil edilmesini istemiş, ancak bunu gerçekleştirememiştik. Ayrıca filmin gösterimi Ankara' da yapılacağı için, ağırlıklı olarak Ankara'dan görüşmecilere yer vermiştik. Elimizdeki yüzlerce saatlik görüşme kayıtlarını izleyerek ve deşifreleri okuyarak, tematik bir kurgu ile filmi çalıştık. Bu oldukça zor, ancak bir o kadar da keyifli bir deneyimdi. Ekip olarak ortaya çıkan filmi tartışarak yeniden biçimlendirsek de, filmin son halinden pek de memnun değildik. Birbirini tekrar eden anlatılara, az sayıda görüşmeciye odaklanmıştık. Film, görüşmelerin bütününü temsil etmiyordu, ancak ne yaptığımız fikrini ortaya koyuyordu. Film seyircilerle buluşurken, ekibimizden bursiyer arkadaşlarımız da filmi seyreden seyircileri kaydediyordu. Görüşmecilerin kendilerini nasıl görecekleri, nasıl değerlendireceklerini, tepkilerini 
böylece görebilecektik. Tematik ve estetik olarak bizleri pek de tatmin etmeyen film, salonda merakla ve keyifle izlendi. Filmde, bir filmin ismini anımsamaya çalışan görüşmeciye, salondan başka seyirciler, o filmin ismini hatırlatıyordu. Film, iyi bir etkileşim yakalamış, samimi, duygusal, yer yer melankolik bir atmosfer oluşturmuş̧tu. Zira filmde konu edilen filmler, sinema salonları ve deneyimler, şimdi yoktu ve bu yokluğa, araştırmacı olarak bizler olduğu gibi, seyirciler de hayıflanıyordu. Film gösterimi sonrasında araştırma ekibi olarak ${ }^{2}$ saha deneyimlerimizi ve gözlemlerimizi paylaştı̆̆ımız bir de söyleşi planlamıştık. Söyleşi için masa ve sandalyeler olmaksızın sahne önünde oturmak biçiminde yaptığımız seçim de, filmin yarattığı samimi ve duygusal atmosferi besleyerek, etkin bir seyirci katılımını tetikledi. Pek çok seyirci, filmin ve projenin önemini vurgulayarak kendi sinema deneyimlerini bizlerle paylaşabileceğini belirttiler. Kendilerince önemli olduğunu düşündükleri bilgileri, söyleşi sonrası yanımıza gelerek aktardılar, yeni görüşmeciler önerdiler.

Sergi boyunca görüş ve düşüncelerin aktarılması için koyduğumuz Sergi Defteri de düşünümselliği tartışmak için önemli veriler içermekteydi. Deftere yazılanlar, ziyaretçilerin sinemaya olan sevgilerini, 60'lı, 70'li yılların sinemasına, Yeşilçam'a özlemlerini yansitıyor ve sinemanın, sanatın önemine işaret ediyordu. Dinlediğimiz, kaydettiğimiz sinemaya gitme anlatıları, geçmiş sinemaya deneyiminin anımsanmasında yeni kuşak için bir postbellek işlevi görmeye başlamıştı ve bu bellek, geçmişe özlem yüklüydü. Böylece görüşmecilerin sinemaya gitme deneyiminin hikâye edilmesinde olduğu gibi, ziyaretçilerin de sergi ve filme ilişkin kavrayışlarında bugünün bağlamının belirleyici olduğu görülmekteydi.

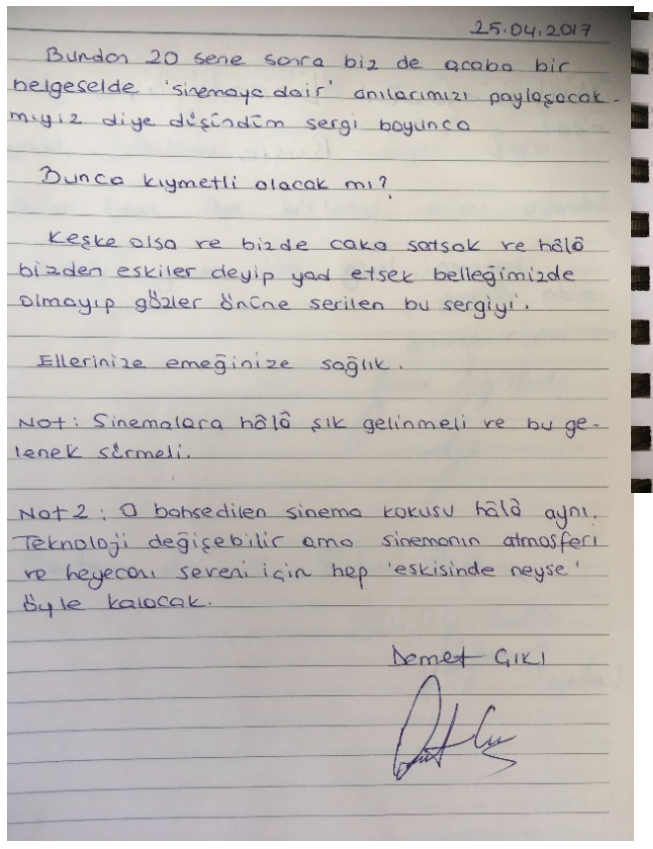

Sergi Defterinden notlar. 


\section{Bitirirken: Araştırmacı olarak varlığım, çatlaklardan sızanlar ve eksiklikler}

Araştırmacı olarak varlığımın, araştırma sürecinde farklı biçimlerde eksiklikler görmek, sanırım saha çalışmasının eşşsiz deneyimlerinden biriydi. Bu deneyimlerden biri de, araştırdığım 1960-1980 arası dönemde Türkiye'de sinema seyirciliği konusu ile katılımcıları belirli anılarını anlatmaları için de kışkırtmış olabileceğimi fark etmekti. Araştırdığım konu, belki de onlardan anlatmalarını beklediğim dönemin kültürel canlılı$\breve{g} 1$ ve buna tanıklık etmekten doğan hazd1. Toplumsal çerçevelerin, bireylerin hatıralarını şekillendirdiğini, ancak sonuç olarak hatırlama eylemini gerçekleştirenin yine de bireyler olduğunu vurgulayan Olick'e (2014: 186) kulak verirsek, benim de katılımcıların hatırlarını biçimlendiren o toplumsal çevreden biri olduğumu söyleyebilirim. Hatta o yaşlarda olmasam da, sahip olduğum değerler ve kültürel modernleşmeye atfettiğim önem nedeniyle, kendimi görüşme yaptığım katılımcıların kuşağının bir parçası olarak bile görebilirim. "Kuşakları nesnel dönemlere göre değil, öznel olarak tanımlanmış yaş grupları olarak yeniden tanımlayan bir yaklaşıma göre bir kuşak, ancak belirli bir yaş grubu kendilerine dair bir cemaat algısı yaratan ortak bir tarihsel deneyimi paylaştıklarında var olur" (Olick, 2014: 188). Öte yandan katılımciların sinemaya gitme deneyimlerine dair anlatılarında kayıp geçmişi yücelten anektodlara vurgu yaparak, onların ürettiği anlatı metinlerini (narrative text), belirli bir sosyal metin (social text) içine yerleştirmiş olabileceğimi de düşünmeye başladım. Belki de Michael Herzfeld'in riskli olduğunu belirttiği gibi (1984: 439), araştırmacı olarak belirli bir dönemde sinemaya gitmiş insanların kültürel özellikleri hakkında genelleme yaptım ve onları belirli ideolojik ve toplumsal değerler dizisi ekseninde belirli kültürel pratikler üretmiş bir kuşak olarak tanımlamayı seçtim. Bunun çalıştığım/ görüşme yaptığım insanlar için bazı kalıplaşmış düşünceleri sürdürmeye yardım etme anlamında risk oluşturduğunun farkındayım. Ancak şimdinin ideolojik ve tarihsel ikliminde bunun anlaşılır olduğunu da düşünüyorum. Sahada görüştüğüm sinema seyircileri, bu tarihsel deneyimi paylaşmaları nedeniyle bir kuşaktı ve geçmişi, benzer biçimde hikâye ediyordu.

"Farklı dönemlerde doğmuş bireyler kendilerinden önce gerçekleşmiş olayları nası1 hatırlıyor ve değerlendiriyorlar? Cevap çoğunlukla kişilerin söz konusu olayı bizzat yaşayıp yaşamadıklarına ve eğer yaşamışlarsa o sırada kaç yaşında olduklarına göre değişiyor; tarihsel olaylar daha çok gelişme çağındaki insanların aklında yer tutuyor. Dolayısıyla, bu çalışmaya göre, tarihsel belleğin belirginleşmesi ve gelişmesi, büyük ölçüde bir kuşağa ait olmanın etkisiyle şekillenmektedir: kuşak ve bellek, toplumsal ya da kültürel yapının nesnel bazı özellikler nedeniyle değil, deneyimdeki ortaklıklar ve tarihsel olayların bireysel bellekte doğurduğu benzerliklerden dolayı birbirlerini karşılıklı olarak kurarlar. Kuşak yapıları ne kadar nesnelleştirilirse nesnelleştirilsin, bireysel deneyimler bu yapının temel aracı olarak kalır“" (Olick, 2014: 188-189).

Bir kuşak olarak görüştüğüm katılımcıların geçmiş inşalarında büyük ortaklıklar olduğunu görsem de, bu bakış açısıyla farklılıkları, rutinden, ritüel olandan sapmaları görmezden gelme riskine de düşmemek, anlatılardaki ortak örüntülerde dahi farklılık- 
ları, çatlakları görmek gerekiyordu. Tam da bu bilgiyle anlatılarda örtülü olan sınıfsal, etnik, cinsel, rrksal konumlanışları görmeye başladım ve pek çok katılımcının anlatısında, şimdi sayıları azalmış olan gayrimüslimlerin nasıl da belirdiğini gördüm. Huyssen (1999: 13) sinemanın dilde, anlatıda, görüntüde ya da kaydedilmiş seslerde bütün temsil biçimleriyle tarihsel olaylara karşı bellek kaybına uğrayan toplumun/grupların/bireylerin bastırılanı hatırlamaları, sorgulamaları ve yüzleşmeleri için kullanılan araçlardan biri olduğunu söyler. Öte yandan film seyretme eyleminin kendisi de, bizatihi bellek açısından kimi çıkarımlar yapmaya olanak verir. Saha çalışmasında yaptığımız görüşmeler de böylesi bastırılan anıların tekrar ortaya çıkmasına neden olmuştu. Gayrimüslimler, bu anlatılarda eğitimli, kültürlü, görgülü, nezaketli ve incelmiş zevklere sahip olarak inşa ediliyordu ki, bu inşa, resmi söylemdeki inşadan farklıydı. Sinema deneyimi Bostancı ve Caddebostan'da yoğunlaşan Yasemin Yalın'ın (1957, Rize) anlatısında gayrimüslimler, sıradan ve "halk" kalabalığ 1 karşısında alt yazısız film izlemeye olanak veren bir yabancı dil bilgisine sahip, nezih ve "farkll" olarak konumlanıyordu ve katılımcının, böylesine nezih bir döneme tanıklık etmekten kaynaklı yaşadığı duygu tarif edilemezdi." "Biz sadece grubun üyeleri olarak hatırlamayız; aynı zamanda bu grupları ve üyelerini de hatırlama eylemiyle eş zamanlı olarak (bu nedenle "re-membering") kurarız" (Olick, 2014: 194). Yasemin Hanım, gayrimüslim olmasa da, o ayrıcalıklı deneyime tanıklı etmiş bir seyirci olarak, kendisini de "o güzel insanlarla" birlikte kuruyordu. Yasemin Hanımla yaşadığımız bu deneyim, bana araştırma kapsamında neden gayrimüslimlerle görüşmediğimi düşündürdü. Araştırmama konu olan 1960'lar ve 70'ler, filmlerde evin sadık hizmetkârı, yardımsever iyi ya da genelev patroniçesi olarak temsil edilen Ermenilerin ve Rumların İstanbul'da yaşadığı yıllardı. Tam da bunu düşünürken, okula gitmeye çalıştığım bir sabah, ilginç bir olay yaşadım. Ayrılık Çeşme'deki Marmaray istasyonunda 70'li yaşlarda bir erkeğin, en çok 60'lı yaşlarında görünen karşısındaki bir kadına, "Efendim İstanbul çok değişti çok. Doğudan gelenler bu şehri mahvetti." biçimindeki ayrımcı konuşmalarına tanık oldum. ${ }^{4}$ Tam turnikelerden geçmek üzereyken duyduğum bu ayrımcı ifadelerin sahibi olan "amcaya", "had bildirmek" üzere yanlarına doğru gidip, "Söylediklerinizi duydum ve böyle konuştuğunuz için sizi çok ayıplıyorum. İstanbul'daki olumsuz değişimi, belirli bir gruba, Doğudan gelenlere atfedip onları suçlayamazsınız. Lütfen dikkat edin!” Araya girişimle şaşıran adam, üsteleyerek, "Öyle değil mi ama! Kenti bilmiyorlar, köylerinde çıkıp burayı da batırıyorlar." Tekrar yaptığı şeyin ayrımcılık, bir tür faşizm olduğunu, kenti kimseye yasaklayamayacaklarını, eleştirecekse insanları göçe zorlayan koşulları, beceriksiz siyasetçileri eleştirmesi gerektiğini söylemem üzerine, etrafımda bizi seyreden bir halka olduğunu fark ettim. Yaptığım şey, Brezilyalı tiyatro kuramcısı ve aktvisti Augusto Boal'ın görünmez tiyatrosuna çok benziyordu. Bu kez bizi seyredenlerden biri de, bana hak vererek hızla uzaklaştı. Benimle baş edemeyeceğimi anlayan ya da on olayı uzatmak istemeyen adam, karşısındaki kadına dönüp, "Bakın, gerçek İstanbullu o. Bir İstanbul Hanımefendisi" diye konuyu değiştirdi. Konuşmalarını böldüğ̈̈m için özür dilediğim kadın, nezaketli biçimde bir şeyler söylediğinde, aksanından onun "yerli" değil, "ötekileştirilen" bir gayrimüslim olduğunu anladım. Adam, az sonra 
Atina’ya dönecek olan eski komşusunu yolculamaya gelmişti ve yol, onun için burada sonlanıyordu. Bu nahoş karşılaşma, o an beni başka bir şey için çok heyecanlandırdı. Yeni Kapı Marmaray durağına kadar adının Eleni olduğunu öğrendiğim hanıma ben eşlik ettim ve bu tür ayrımcılıklara tahammül edemediğimi belirterek bir kez daha özür diledim. Eleni Hanım, İstanbulluydu ve Moda'da yaşamıştı. Ancak 6-7 Eylül olayları ve ardından 1974'teki Kıbrıs çıkarması sonucu, Türkiye'de yaşama koşulları kalmadığg için Yunanistan'a göç etmek zorunda kalmıştı. Israrla buralı olduğunu, burayı sevdiğini ve kendisini Türkiyeli hissettiğini söylüyordu. Üstelik yerleştiği Atina’da da benimsenmemiş, ötekileştirilmişti. Tam da bu nedenle onu uğurlamaya gelen komşusunun yaptığ1 şeyin tehlikeli olduğunu, onun buradan gitmesine neden olan şeyin ardında böylesi bir ayrımcılığgn yattığııı söyledim. Gülerek, "Haklısınız” dedi. Bu kısa yolculukta Moda'da sinemaya gittiğini öğrendiğim Eleni Hanımın iletişim bilgilerini aldım, ancak her yıl Mayıs ayında geldiği Türkiye'de ona bir daha ulaşamadım. Görünmez tiyatro yapmama neden olan bu karşılaşma, önceleri yalnızca kuramsal olarak farkında olduğum bir gerçeğin, seyircinin ulusal kimliğinin, sinemaya gitme deneyiminde nasıl bir rol oynadığı üzerine daha ciddi düşünmeme vesile oldu. Hala anlamlı çıkarımlar yapmama yetecek sayıda gayrimüslim seyirciye ulaşmak ve bu konuyu çalışmak istiyorum. Bir araştırmacı olarak araştırma sürecinde yeni deneyimler edindim ve tıpkı katılımcılarımız gibi, bu deneyimleri anlatılara dönüştürüyorum. Görüşmecilerimin anlattığı gibi geçmiş yıllara ait anlatacağım sinema anılarım olmasa da, onlarla sahada yaptığım görüşmelerle edindiğim deneyimlerim ve bu deneyimlerimle örülmüş anlatılarım var. Ve ben onları anlatmaya, yazmaya devam edeceğim. Şimdi olduğu gibi.

\section{Notlar}

${ }^{1}$ Seçil Büker ile olan görüşmede, araştırma ekibimizden Ruken Öztürk ve bursiyer öğrencimiz Mert Öner de hazır bulunmuştu

2 Hasan Akbulut, Ruken Öztürk, Emine Uçar İlbuğa, Mert Gürer ve Arda Kaya.

${ }^{3}$ Toplumcu şair Gülten Akın'ın bu şiiri şöyle başlar: Ah, kimselerin vakti yok/ Durup ince şeyleri anlamaya/ Kalın fırçalarını kullanarak geçiyorlar/ Evler çocuklar mezarlar çizerek dünyaya/ Yitenler olduğu görülüyor bir türküyü açtılar mı/ Bakıp kapatıyorlar/ Geceye giriyor türküler ve ince şeyler...

${ }^{4}$ Yalın, Caddebostan ve Bostancı arasında kurduğu karşıtlığı şöyle ifade ediyor: “(Caddebostan'dakiOzan Sineması, işte hep yazlıkçılar vardı orada. Hep gayrimüslimler daha çoktu yazlığa geldikleri için. Daha nezih kişiler. O yaşta olduğum halde hatırlıyorum. Hep söylerim Ozan Sineması başka idi... . Daha kültürlü kişiler çünkü yabancı film geliyor okuyana kadar görmüyorsun orjinal olduğu için okuyana kadar gidiyor zaten. Ama öbür taraf halk sineması. Halk sineması diyorum artık" (Yasemin Yalın, 1957, İstanbul).

5 "Doğudan gelenler", adı konulmamış bir etnik kategori olarak Kürtleri imler. Ancak sözlerin sahibi olan adam, isimsiz bırakarak da bir kez daha onları ötekileştiriyordu. 


\section{Kaynaklar}

Abrams, L. (2016) Oral history theory. New York: Routledge.

Akbulut, H. (2016) "Sinemaya gitmek ve seyir: bir sözlü tarih çalışması", Türk Film Araştırmalarında Yeni Yönelimler 12, (içinde) Yay. Haz. Deniz Bayrakdar. İstanbul: Bağlam, 231-252.

Atay, T. (2017) "Sosyal antropolojide yöntem ve etik sorunu: klasik etnografiden diyalojik etnografiye doğru”, Moment Dergi: Hacettepe Üniversitesi İletişim Fakültesi Kültürel Çalışmalar Dergisi, 4(1): 189-206. DOI: https://doi.org/10.17572/mj2017.1.189206. Erişim Tarihi 1 Ağustos 2017.

Boym, S. (2009) Nostaljinin geleceği. (Çev. F. B. Aydar). İstanbul: Metis.

Casetti, F. (2011) "Sinemasal deneyim”, (Çev. D. Kırmızı). Sinecine: Sinema Araştırmaları Dergisi, 2 (2): 81-93.

Creswell, J. W. (2012) Educational research: Planning, conducting, and evaluating quantitative and qualitative research. 4. Ed. Boston: Pearson.

Emerson, Robert M. vd. (2008) Bütün yönleriyle alan çalışması: Etnografik alan notları yazımı (Çev. A. E. Koca). Ankara: Birleşik.

Gupta, A.; F. James (1997) Discipline and practice: 'The field' as site, method, and location in anthropology, Antrophological Locations: Boundaries and Grounds of a Field Science. Ed. AkhilGupta, James Ferguson. (s. 1-46). University of California Press: Berkeley, Los Angeles, California.

Halbwachs, M. (2016) Hafizanın toplumsal çerçeveleri, Çev. B.Uçar. Ankara: Heretik.

Hammersley, M.; Atkinson, P. (2007) Ethnography: Principles in practice. 3rd edition. London: Routledge.

Hastrup, K. (2004) "Getting it right: knowledge and evidence in anthropology", Anthropological Theory 4: 455-72.

Hervik, P. (1994) "Shared reasoning in the field. reflexivity beyond the author", Kirsten Hastrup \& Peter Hervik (Ed.), Social experience and anthropological knowledge, (s. 78-100) London and NY: Routledge.

Herzfeld, M. (1984) "the horns of the Mediterraneanist dilemma", American Ethnologist: Jorunal of the American Ethnological Society, 11 (3): 439-454.

Hirsch, M. (2001) "Surviving 1mages: holocaust photographs and the work of postmemory", The Yale Journal of Criticism, 14 (1): 5-37

Huyssen, A. (1999) Alacakaranlık anıları: Bellek yitimi kültüründe zamanı belirlemek, (Çev. K. Atakay). İstanbul: Metis.

Kondo, D. K. (1986) Dissolution and reconstitution of the self: Implications for anthropological epistemology, Cultural anthropology, 1: 74-96.

Kottak, C. P. (2002) Antropoloji: Insan çeşitliğine bir bakış, (Çev. S. Altuntek vd.) Ankara: Ütopya.

Kuhn, A. (2002) An everyday magic: Cinema and cultural memory. London, New York: I.B. Tauris. 
Marcus, G. E.; Fisher, Micahel M. (2013) Kültürel eleştiri olarak antropoloji: Insan bilimlerinde deneysel bir an (Çev. B. Cezar). İstanbul: Koç Üniversitesi.

Nahya, Z. Nilüfer; Harmanşah, Rabia (2016) "Kendini ve ötekini yazmak: Alan araştırması ve deneyim", Etnografik hikâyeler: Türkiye'de alan araştırması deneyimleri (Ed. Z. N. Nahya, R. Harmanşah.) (s.17-34) Ankara: Metis.

Olick, Jeffrey K. (2014) “Kolektif bellek: İki farklı kültür”, (Çev. M. Güneşdoğmuş). Moment Dergi, 1(2): 175-211.

Sarlo, B. (2012) Geçmiş zaman: Bellek kültürü ve özneye dönüşüzerine bir tartışma. İstanbul: Metis.

Summerfield, P. (1998) Reconstructing women's wartime lives. Manchester, New York: Manchester University.

Tedlock, B. (1991) "From participant observation to the observation of participation: The emergence of narrative ethnography", Journal of Anthropological Research, 47(1), 6994.

Thorne, B. (1980) "You still taken notes: Fieldwork and problems of informed consent", Social Problems, 27 (3): 284-297.

Thompson, P.l (1999) Geçmişin sesi: Sözlü tarih (Çev. Ş. Layıkel). İstanbul: Tarih Vakfı Yurt.

Tomsic, M. (2005) "Women's memories of cinema-going: More than the only thing left to do in Victoria's western district", History Australia, 2 (1): 6-1-12. DOI number: http:// dx.doi.org/10.2104/ha040006.

Tyler, S. (1986) "Post-modern ethnography: from document of the occult to occult document," J. Clifford, G. Marcus (Ed.), Writing culture: The poetics and ethnography (s. 122-140). Berkeley, Los Angeles, London: University of California. 